\title{
PENGARUH KEMAMPUAN MANAJERIAL DAN MOTIVASI TERHADAP KINERJA PEWIRAUSAHA KECIL/MIKRO MELALUI KEPUASAN KERJA
}

\author{
Rina Irawati \\ Sekolah Tinggi Ilmu Ekonomi (STIE) Malangkuçeçwara Malang \\ e-mail: rinaira@stie-mce.ac.id \\ HP 081555611655
}

\begin{abstract}
Abstrac
This study aimed to examine the direct and indirect effects between managerial ability and motivation of the micro entrepreneur through job satisfaction. Entrepreneur survey respondents is 93 in small region Kedawung Road Kalpataru Blimbing Malang district, with the technique of simple random sampling. Methods of analysis using regression analysis, followed by the path analysis (path-analysis). Validity and reliability of test results prove that all the items variable is valid and reliable (alpha above 0.6). The test results proved the hypothesis that there is no indirect effect between managerial ability and motivation of the entrepreneur performance through job satisfaction. This is evidenced by the insignificant effect on performance entrepreneur managerial skills and managerial capabilities insignificant effect on job satisfaction. Using path analysis, the model found a new path to eliminate the influence of managerial capability variables (X1).
\end{abstract}

Kata kunci: kemampuan manajerial, motivasi, kepuasan kerja, kinerja, analisis jalur.

Saat ini lapangan pekerjaan di sektor formal semakin berkurang, sedangkan lulusan sarjana ataupun diploma (sarjana muda) setiap tahun semakin meningkat. Fakta ini membuktikan bahwa pemikiran kreatif dan inovatif para sarjana ini harus lebih banyak dikembangkan agar dapat membuka peluang usaha baru. Tidak hanya bergantung dan berharap penuh dengan pemerintah atau instansi swasta lainnya. Banyak lulusan sarjana yang lebih sebagai pencari kerja (job seeker) daripada pencipta kerja (job creator). Padahal dunia wirausaha merupakan pilihan yang rasional dalam situasi dan kondisi yang tidak bisa diandalkan ini. Tetapi dengan adanya suatu persepsi negatif yang memunculkan imej buruk bahwa wirausaha itu adalah pekerjaan yang kurang menjanjikan dan memberi tantangan besar, mengakibatkan banyak orang kurang berani melakukan wirausaha. Persepsi negatif ini sebenarnya berupa keyakinan-keyakinan subyektif yang tidak mengandung kebenaran obyektif. 
Prasangka buruk ini disebut dengan mitos, dan mitos ini harus segera dihilangkan (Ifham, 2010).

Tidak seimbangnya jumlah tenaga kerja dengan lapangan pekerjaan membuat pemerintah melaksanakan program untuk meningkatkan kewirausahaan di kalangan masyarakat. Kewirausahaan diharapkan dapat membantu perekonomian bangsa. Menurut Mc Clelland, idealnya sebuah negara akan maju jika minimal 2\% penduduknya menjadi wirausaha, entah pengusaha mikro, kecil, menengah ataupun pengusaha besar. Di negara lain seperti Amerika Serikat memiliki 12\% pengusaha dari total penduduknya, Singapura 7\%, Cina dan Jepang sekitar 10\%. Sedangkan di Indonesia baru 0,18\% saja yang menjadi wirausaha/entrepreneur. Artinya baru 450.000 penduduk Indonesia yang membuka usaha sendiri dan tidak bergantung bekerja pada orang lain (http:/ / jarno.web.id).

Sektor informal umumnya merupakan usaha skala kecil dengan modal, ketrampilan dan pengembangan yang sangat terbatas. Salah satu bentuk usaha sektor informal adalah berwirausaha, baik di sektor pelayanan jasa ataupun pembuatan produk. Wirausaha merupakan usaha kecil yang berorientasi pada laba dimana mereka mempunyai cara tersendiri dalam mengelola usahanya agar mendapatkan keuntungan seperti yang diharapkan. Selain itu pewirausaha akan menjadi manajer tunggal yang menangani usaha mulai dari perencanaan usaha apa yang akan dilakukan, mengontrol, mengawasi, dan mengendalikan usaha tersebut. Kegiatan itu mereka lakukan dengan semaksimal mungkin agar usaha yang dijalankan dapat berkelanjutan. Namun dengan belajar dari pengalaman diharapkan semua usaha dapat dijalankan dengan baik.

Kemampuan manajerial sangat diperlukan oleh pewirausaha untuk meningkatkan kinerja usahanya, karena mereka harus mampu mengelola usahanya dengan melakukan perencanaan, pengorganisasian, pengarahan dan pengawasan, yang disertai dengan keterampilan teknis, ketrampilan manusiawi dan ketrampilan konseptual. Diharapkan dengan meningkatnya kemampuan manajerial, mereka akan mampu mengelola usahanya serta mampu bertahan dalam persaingan yang cukup tinggi sehingga usahanya dapat berkembang lebih maju dan tingkat kesejahteraan lebih baik (Karweti, 2010).

Motivasi yang tinggi yang timbul dari diri seorang pewirausaha akan memberikan dampak yang tinggi untuk melakukan kegiatan usaha, memacu dan 
mengembangkan usaha. Motivasi merupakan dorongan yang timbul dan membuat orang bertindak atau berperilaku dalam cara-cara tertentu sesuai dengan keinginan yang diharapkan untuk selalu maju dalam mengembangkan usahanya. Jadi motivasi merupakan unsur yang dapat menggerakkan seseorang untuk melakukan usaha yang lebih baik dari sebelumnya.

Setiap orang yang mendirikan usaha tentunya menginginkan tercapainya laba dan perkembangan usaha yang pesat. Hal ini tercermin dari kinerja usaha yang dicapai. Kinerja usaha didefinisikan sebagai prestasi kerja yakni perbandingan antara hasil kerja yang secara nyata dengan standar kerja yang ditetapkan (Devi, 2009). Agar kinerja usaha dapat terwujud sesuai dengan yang diinginkan, salah satu cara adalah dengan mengupayakan tercapainya kepuasan kerja. Kepuasan dalam menjalankan pekerjaan merupakan hal penting bagi kinerja atau produktivitas seseorang. Suatu gejala yang dapat membuat rusaknya kegiatan wirausaha adalah rendahnya kepuasan pewirausaha dimana timbul gejala seperti: malas bekerja, banyaknya keluhan dari para pekerja dan konsumen, rendahnya prestasi kerja, rendahnya kualitas layanan kepada konsumen, indisipliner pekerja, dan lain-lain (Syaiin, 2008). Meningkatkan kepuasan kerja kerja pewirausaha merupakan hal yang penting karena menyangkut masalah hasil kerja yang merupakan salah satu langkah dalam meningkatkan mutu pelayanan kepada konsumen.

Kota Malang merupakan kota terbesar kedua di Jawa Timur setelah Surabaya. Dengan perkembangan kota yang sangat pesat dari tahun ke tahun, mendorong masyarakat Malang untuk terjun ke dunia bisnis/usaha yang dipandang memiliki prospek bagus. Usaha yang dibidik masyarakat terutama usaha kecil/mikro. Dari observasi yang dilakukan, di sepanjang jalan Kedawung dan Kalpataru di wilayah Kecamatan Lowokwaru Kotamadya Malang terdapat banyak sekali kegiatan wirausaha. Hampir sebagian besar rumah yang dimiliki warga masyarakat di daerah tersebut (terutama yang terletak di pinggir jalan) dijadikan tempat usaha berskala kecil/mikro. Jalan Kalpataru dan Kedawung ini tergolong jalan yang ramai, dilalui oleh berbagai jalur angkot (mikrolet), taksi, kendaraan pribadi, dan lain-lain. Wilayah jalan ini dikelilingi oleh banyak sekolah, madrasah, dan pondok pesantren. Selain itu jalan Kedawung-Kalpataru diakses oleh banyak orang karena merupakan jalan alternatif menuju banyak kampus (baik PTN maupun PTS) dan ke wilayah Batu. Oleh karena itu, tidaklah mengherankan jika masyarakat di wilayah jalan Kedawung- 
Kalpataru ini beramai-ramai mendirikan usaha kecil/mikro (berwirausaha), terutama bagi mereka yang memiliki rumah di pinggir jalan tersebut. Rumusan masalah dalam penelitian ini adalah: (1) Bagaimana pengaruh kemampuan manajerial dan motivasi terhadap kinerja pewirausaha kecil/mikro?, dan (2) Bagaimana pengaruh kemampuan manajerial dan motivasi terhadap kinerja pewirausaha kecil/mikro melalui kepuasan kerja?

\section{Kemampuan Manajerial}

Kemampuan manajerial adalah seperangkat keterampilan teknis dalam melaksanakan tugas sebagai manajer untuk mendayagunakan segala sumber yang tersedia untuk mencapai tujuan usaha secara efektif dan efisien (Karweti, 2010). Kemampuan manajerial menurut Siagian (1997) adalah kemampuan untuk mengelola usaha seperti perencanaan, pengorganisasian, pemberian motivasi, pengawasan dan penilaian. Jadi dapat di simpulkan bahwa kemampuan manajerial adalah kemampuan untuk menggerakan orang lain dalam memanfaatkan sumber-sumber yang ada dalam mencapai tujuan organisasi secara efisien dan efektif. Ukuran seberapa efisien dan efektifnya seorang manajer adalah seberapa baik dia menetapkan rencana dalam mencapai tujuan yang memadai, kemampuan memimpin secara efektif merupakan kunci keberhasilan organisasi.

Menurut Paul Hersey dkk (dalam Karweti, 2010), dalam rangka pelaksanaan tugas-tugas manajerial, paling tidak diperlukan tiga macam bidang keterampilan yaitu: technical, human dan conceptual. Ketiga keterampilan manajerial tersebut berbedabeda sesuai dengan tingkat kedudukan manajer dalam organisasi. Robbins (2003) menyatakan bahwa keterampilan konseptual (conceptual skills) merupakan kemampuan mental untuk menganalisis dan mendiagnosis situasi yang rumit. Dalam hal ini seorang pewirausaha harus memiliki keterampilan konseptual dalam hal: (1) Kemampuan analisis, (2) Kemampuan berfikir rasional, (3) Ahli atau cakap dalam berbagai macam konsepsi, (4) Mampu menganalisis berbagai kejadian dan mampu memahami berbagai kecenderungan, (5) Mampu mengantisipasi perintah, dan (6) Mampu menganalisis macam-macam kesempatan dan problem-problem sosial (Karweti, 2010).

Sedangkan keterampilan teknik (technical skills) meliputi kemampuan dalam menerapkan pengetahuan atau keahlian spesialiasi (Robbins, 2003). Menurut Karweti 
(2010), keterampilan teknis yang harus dimiliki seorang pewirausaha adalah: (1) Menguasai pengetahuan tentang metode, proses, prosedur dan tehnik untuk melaksanakan kegiatan khusus, dan (2) Kemampuan untuk memanfaatkan serta mendayagunakan sarana, peralatan yang diperlukan dalam mendukung kegiatan yang bersifat khusus. Keterampilan manusiawi (human skills) adalah kemampuan bekerjasama, memahami dan memotivasi orang lain, baik perorangan maupun kelompok (Robbins, 2003). Karweti (2010) menyatakan bahwa keterampilan manusiawi seorang pewirausaha meliputi: (1) Kemampuan memahami perilaku manusia dan proses kerjasama, (2) Kemampuan untuk memahami isi hati, sikap dan motif orang lain, mengapa mereka berkata dan berperilaku, (3) Kemampuan untuk berkomunikasi secara jelas dan efektif, (4) Kemampuan menciptakan kerja sama yang efektif, kooperatif, praktis dan diplomatis, serta (5) Mampu berperilaku yang dapat diterima.

\section{Motivasi}

Menurut Samsudin (2005), motivasi adalah proses mempengaruhi atau mendorong dari luar terhadap seseorang atau kelompok kerja agar mereka mau melaksanakan sesuatu yang telah ditetapkan. Motivasi atau dorongan (drive force) dimaksudkan sebagai desakan yang alami untuk memuaskan dan mempertahankan kehidupan. Sedangkan Siswanto (2008) mengemukakan bahwa motivasi sebagai kebutuhan sekaligus sebagai pendorong yang dapat menggerakkan semua potensi, baik karyawan maupun sumber daya lainnya. Menurut French dan Raven (dalam Sule, 2008), motivasi adalah sesuatu yang mendorong seseorang untuk menunjukkan perilaku tertentu. Dari beberapa definisi di atas dapat diambil kesimpulan bahwa motivasi merupakan sesuatu yang penting untuk dipahami oleh manajer karena motivasi merupakan faktor pendorong mengapa individu atau sumber daya manusia dalam organisasi berperilaku dan bersikap dengan pola tertentu, termasuk juga terkait dengan kinerja yang ditunjukkan oleh individu tersebut.

Menurut Gitosudarmo dalam Adonia (2007), teori motivasi terbagi menjadi 2 kategori yaitu: Teori Kepuasan (Content Theory) dan Teori Proses (Process Theory). Teori kepuasan berkaitan dengan faktor-faktor yang ada dalam diri seseorang yang memotivasinya. Sedangkan teori proses berkaitan dengan bagaimana motivasi itu terjadi atau bagaimana perilaku itu digerakkan. 


\section{Kepuasan Kerja}

Seseorang akan meningkatkan produktivitas atau kinerjanya jika memperoleh kepuasan kerja sesuai dengan apa yang diharapkan. Wiyono (1999) dalam Syaiin (2008) menyatakan bahwa kepuasan kerja adalah tingkat keadaan yang dirasakan seseorang yang mempunyai hasil dari membandingkan penampilan atau outcome produk yang dirasakan dalam hubungannya dengan harapan seseorang. Locke dalam Devi (2009) menjelaskan bahwa kepuasan kerja mencerminkan kegembiraan atau sikap emosi positif yang berasal dari pengalaman kerja seseorang. Robbins (2003) berpendapat bahwa kepuasan kerja adalah suatu sikap umum terhadap pekejraan seseorang sebagai perbedaan antara banyaknya ganjaran yang diterima pekerja dengan banyaknya ganjaran yang diyakini seharusnya diterima. Dari beberapa definisi di atas dapat disimpulkan bahwa kepuasan kerja merupakan keadaan emosional yang menyenangkan atau tidak menyenangkan dengan seseorang memandang pekerjaan mereka.

Menurut Robbins (2003) faktor-faktor yang mempengaruhi kepuasan kerja antara lain: (1) Pekerjaan yang secara mental menantang, (2) Gaji atau upah yang pantas, (3) Kondisi kerja yang mendukung, (4) Rekan kerja yang mendukung, (5) Kesesuaian kepribadian dengan pekerjaan. Gilmer dalam Parwanto (2009) menyatakan bahwa faktor-faktor yang mempengaruhi kepuasan kerja adalah: (1) Kesempatan untuk maju, (2) Keamanan kerja, (3) Gaji, (4) Perusahaan dan manajemen, (5) Faktor intrinsik dan pekerjaan, (6) Kondisi kerja, (7) Aspek sosial dalam pekerjaan, (8) Kondisi kerja, (9) Aspek sosial dalam pekerjaan, (10) Komunikasi, serta (11) Fasilitas.

Sementara itu menurut Heidjrachman dan Husnan (dalam Parwanto, 2002) mengemukakan faktor-faktor kepuasan kerja antara lain: (1) Gaji yang baik, (2) Pekerjaan yang aman, (3) Rekan kerja yang kompak, (4) Penghargaan terhadap pekerjaan, (5) Pekerjaan yang berarti, (6) Kesempatan untuk maju, (7) Pimpinan yang adil dan bijaksana, (8) Pengarahan dan perintah yang wajar, serta (8) Organisasi atau tempat kerja yang dihargai oleh masyarakat.

\section{Kinerja Pewirausaha}

Dessler (dalam Devi, 2009) mendefinisikan kinerja sebagai prestasi kerja, yakni perbandingan antara hasil kerja yang secara nyata dengan standar kerja yang 
ditetapkan. Hasibuan (2009) menjelaskan bahwa kinerja merupakan hasil kerja yang dicapai seseorang dalam melaksanakan tugas-tugas yang dibebankan kepadanya didasarkan pada kecakapan, pengalaman, kesungguhan dan waktu. Menurut Maryoto (dalam Narmodo, 2010) kinerja karyawan adalah hasil kerja selama periode tertentu dibandingkan dengan berbagai kemungkinan, misalnya standar, target/sasaran atau kriteria yang telah disepakati bersama. Dari berbagai definisi di atas, maka dapat disimpulkan bahwa kinerja merupakan hasil kerja selama periode tertentu dibandingkan degan berbagai kemungkinan, misalnya: standar, target atau kriteria yang telah disepakati bersama. Kinerja individu merupakan dasar dari kinerja organisasi.

Untuk mencapai kinerja yang diharapkan, maka perusahaan harus memperhatikan faktor-faktor yang dapat mempengaruhi kinerja. Menurut Gibson dalam Syaiin (2008), faktor-faktor yang dapat mempengaruhi kinerja antara lain: (1) Karakteristik individu, meliputi: umur, jenis kelamin, status pernikahan, tempat tinggal dan pengetahuan; (2) Karakteristik organisasi, meliputi: sumber daya, kepemimpinan, imbalan, supervisi, struktur organisasi dan desain pekerjaan; dan (3) Karakteristik psikologis, meliputi: motivasi, persepsi terhadap pekerjaan. Menurut pendapat Sumanto (2004), faktor-faktor yang mempengaruhi kinerja adalah: (1) Efektifitas dan efisiensi, (2) Otoritas (wewenang), (3) Disiplin, dan (4) Inisiatif.

\section{Usaha Kecil/Mikro}

Alma (2005) menyatakan bahwa istilah kewirausahaan berasal dari terjemahan Entrepreneurship yang diterjemahkan sebagai "perantara". Wirausaha sendiri berasal dari bahasa Perancis, entrepreneur yang artinya adalah "antara". Menurut Meredith (2000), seorang wirausaha atau entrepreneur adalah orang yang mempunyai kesempatan melihat dan menilai kesempatan-kesempatan bisnis, mengumpulkan sumber-sumber daya yang dibutuhkan guna mengambil keuntungan daripadanya dan mengambil tindakan yang tepat guna memastikan sukses. Dari berbagai definisi di atas dapat disimpulkan bahwa kewirausahaan adalah kemampuan berpikir kreatif dan berperilaku inovatif (menciptakan sesuatu yang baru dan berbeda) yang dijadikan dasar, sumber daya, kiat dan proses menciptakan nilai tambah barang dan jasa yang dilakukan dengan keberanian mengambil resiko. Esensi dari kewirausahaan adalah 
menciptakan nilai tambah di pasar melalui proses pengkombinasian sumber daya dengan cara-cara baru dan berbeda agar dapat bersaing.

Pengertian usaha kecil menurut UU no 9 tahun 1995 adalah usaha dengan kekayaan bersih paling banyak Rp 200 juta (tidak termasuk tanah dan bangunan tempat usaha), dengan hasil penjualan tahunan maksimal Rp 1 milyar. Kementrian Negara Koperasi dan UKM (KUKM) menggunakan UU tersebut sebagai dasar dalam mengelompokkan jenis-jenis usaha. Menurut kementrian ini, kelompok usaha mikro termasuk di dalam kelompok usaha kecil. Sementara Departemen Keuangan berdasarkan Keputusan Menteri Keuangan RI no 40/KMK.06/2003, menitikberatkan pada besarnya hasil/pendapatan usaha dalam mendefinisikan usaha mikro maupun usaha kecil. Menurut Kepmen tersebut, usaha mikro adalah usaha produktif milik keluarga atau perorangan WNI dan memiliki hasil penjualan (omzet) maksimal Rp 100 juta per tahun.

Sedangkan BPS (Biro Pusat Statistik) melihat batasan jumlah tenaga kerja dalam menentukan skala usaha terutama di sektor industri, yaitu: (1) Industri kerajinan rumah tangga (IKRT) dengan 1-4 pekerja, dan (2) Industri Kecil (IK) dengan 5-19 pekerja, termasuk pemiliknya. Departemen Perindustrian dan Perdagangan memberikan batasan yang sama dalam membagi skala usaha, yaitu: (1) Industri mikro dengan 1-4 pekerja, (2) Industri kecil dengan 5-19 pekerja, dan (3) Industri menengah dengan 20-99 pekerja. Jumlah omzet per tahun maksimal di bawah Rp 1 juta.

\section{Pengembangan Hipotesis}

\section{Pengaruh Kemampuan Manajerial dan Motivasi terhadap Kinerja Pewirausaha}

Dengan kemampuan manajerial yang dimiliki pewirausaha, baik kemampuan secara teknik, manusiawi dan konseptual dalam melakukan perencanaan, pengorganisasian, pengarahan dan pengendalian, hal ini berdampak pada kinerja pewirausaha yang bersangkutan. Motivasi merupakan fungsi inti dalam manajemen. Dengan motivasi, maka seseorang akan terdorong untuk melakukan suatu kegiatan dengan semaksimal mungkin, demi terwujudnya tujuan yang telah ditetapkan. Di dalam lingkungan perusahaan, sangat dibutuhkan motivasi kerja. Pada hakekatnya motivasi karyawan dan pengusasha berbeda karena ada perbedaan kepentingan. Maka perlu diciptakan motivasi yang searah untuk mencapai tujuan bersama dalam rangka kelangsungan usaha dan ketenangan kerja sehingga apa yang menjadi kehendak dan 
dicita-citakan kedua belah pihak dapat diwujudkan (Vest dan Markham dalam Devi, 2009). Hasil penelitian Sarworini (2007), Karweti (2010), dan Sumanto (2004) membuktikan bahwa terdapat pengaruh secara signifikan dan positif antara kemampuan manajerial terhadap kinerja. Penelitian Devi (2009), Narmodo dan Farid (2010), Sarworini (2007), Karweti (2010), Adonia (2007), dan Sumanto (2004) membuktikan bahwa terdapat pengaruh positif dan signifikan antara motivasi terhadap kinerja. Sehingga dapat dirumuskan hipotesis penelitian sebagai berikut:

$\mathrm{H}_{1}$ : Terdapat pengaruh antara kemampuan manajerial dan motivasi terhadap kinerja pewirausaha.

\section{Pengaruh Kemampuan Manajerial dan Motivasi terhadap Kinerja Pewirausaha Melalui Kepuasan Kerja}

Kemampuan manajerial di sini merupakan kemampuan pewirausaha secara umum dalam mengelola usahanya. Hal ini tercermin dalam kemampuan teknis, kemampuan manusiawi, dan kemampuan konseptual. Dengan kemampuan manajerial yang dimiliki, maka kepuasan kerja pewirausaha akan dapat terwujud. Hasil penelitian Kabai (2008) membuktikan bahwa penilaian guru terhadap kemampuan manajerial kepala sekolah berpengaruh positif dan signifikan terhadap kepuasan kerja guru. Motivasi timbul karena adanya suatu kebutuhan dan karenanya perbuatan tersebut terarah pencapaian tujuan tertentu (Narmodo dan Farid, 2010). Ada hubungan yang kuat antara kebutuhan motivasi, perbuatan atau tingkat laku, dan tujuan terhadap kepuasan kerja. Hasil penelitian Prabu (2005) membuktikan bahwa terdapat pengaruh secara simultan antara faktor-faktor motivasi terhadap kepuasan kerja pada pegawai BKKBN Kabupaten Muara Enim.

Kepuasan kerja merupakan perasaan dan reaksi individu terhadap lingkungan pekerjaannya. Kepuasan kerja yang dialami oleh pewirausaha dalam menjalankan bisnisnya tentu akan berpengaruh terhadap kinerja usahanya. Dengan kepuasan kerja yang tinggi maka diharapkan pewirausaha akan semakin termotivasi untuk meningkatkan kinerja usahanya baik di segi kualitas maupun kuantitas kerja. Hasil penelitian Devi (2009), Syaiin (2008), serta Parwanto dan Wahyuddin (2002) menunjukkan bahwa terdapat pengaruh secara positif dan signifikan antara kepuasan 
kerja terhadap kinerja. Dari hasil penelitian empiris tersebut, dapat dirumuskan hipotesis penelitian sebagai berikut:

$\mathrm{H}_{2}$ : Terdapat pengaruh kemampuan manajerial dan motivasi terhadap kinerja pewirausaha melalui kepuasan kerja.

\section{METODE}

Variabel yang digunakan dalam penelitian ini meliputi: (1) Variabel bebas yang terdiri dari kemampuan manajerial (X1) dan motivasi (X2); (2) Variabel antara yaitu kepuasan kerja (Z); dan (3) Variabel terikat yaitu kinerja pewirausaha kecil/mikro (Y). Pengukuran variabel menggunakan Skala Likert dengan 5 kriteria, yaitu: sangat tidak setuju (skor 1), tidak setuju (skor 2), cukup setuju (skor 3), setuju (skor 4) dan sangat setuju (skor 5). Populasi dalam penelitian ini adalah seluruh pewirausaha kecil/mikro di sepanjang Jalan Kedawung - Kalpataru Kecamatan Blimbing Kotamadya Malang sejumlah 186 orang. Sesuai dengan pendapat Arikunto (1993:107) bahwa "untuk sekedar ancer-ancer apabila subyeknya kurang dari 100 lebih baik diambil semua sehingga penelitiannya merupakan penelitian populasi. Apabila lebih dari 100 maka dapat diambil 10-20\%, 20 - 25\% atau lebih dari jumlah populasi yang ada", maka jumlah sampel dalam penelitian ini adalah $50 \%$ dari populasi yang ada yaitu 93 orang. Tehnik pengambilan sampel menggunakan Simple Random Sampling, yaitu setiap elemen populasi yang mempunyai kesempatan sama untuk dipilih menjadi sampel (Kuncoro, 2003).

\section{Uji Validitas dan Reliabilitas}

Uji validitas digunakan untuk mengukur sah atau valid tidaknya suatu kuisioner (Santoso, 2002). Kuesioner dikatakan valid atau sahih jika mampu mengukur apa yang diinginkan oleh peneliti serta dapat mengungkapkan data dari peubah yang diteliti secara tepat. Teknik yang digunakan untuk mengukur validitas dengan mengkorelasikan skor total item dengan skor masing-masing item (corrected-item total correlation). Dengan kriteria apabila $\mathrm{r}$ hitung $>\mathrm{r}$ tabel, maka item tersebut dikatakan valid. Reliabilitas adalah alat untuk mengukur suatu kuisioner yang merupakan indikator dari variabel" (Santoso, 2002). Untuk mengetahui alat ukur itu reliabel atau tidak dalam penelitian ini, diuji dengan rumus koefisien alpha atau 
disebut dengan alpha cronbach ( ). Ukuran yang dipakai bilamana nilai Cronbach Alpha di atas 0,6 dikatakan reliabel (Santoso, 2002), atau dengan kata lain, apabila nilai alpha berdasarkan hasil perhitungan memiliki nilai di atas 0,6 maka dapat disimpulkan bahwa kuisioner (item dalam kuisioner tersebut) reliabel.

\section{Metode Analisis}

Menggunakan analisis regresi berganda untuk mengetahui pengaruh langsung dan tidak langsung kemampuan manajerial dan motivasi terhadap kinerja pewirausaha melalui kepuasan kerja. Analisis jalur (path analysis) merupakan pengembangan lebih lanjut dari regresi berganda. Analisis Jalur adalah alat untuk eksplanasi atau faktor determinan yang dapat digunakan untuk menentukan variabel mana yang berpengaruh dominan atau jalur mana yang berpengaruh lebih kuat (Solimun, 2002). Dengan analisis jalur dapat diketahui akibat langsung dan tidak langsung antar variabel. Akibat langsung berarti arah hubungan antara dua variabel langsung tanpa melewati variabel yang lain, sementara hubungan tidak langsung harus melewati variabel yang lain (Solimun, 2002).

Untuk mengetahui besarnya sokongan pengaruh setiap variabel $\mathrm{X}$ terhadap $\mathrm{Y}$, dapat digunakan regresi dengan variabel yang dibakukan (standardize). Koefisien analisis jalur diambil dari Standardize Coefficients Beta. Dengan mengubah setiap data amatan ke dalam data standardize, maka semua unit satuan dari setiap variabel adalah hilang dan skalanya menjadi seragam. Dalam model regresi dengan variabel dibakukan, konstanta tidak ada $(=0)$.

\section{HASIL DAN PEMBAHASAN}

Uji validitas didasarkan atas ketentuan jika $r$ hasil $>r$ tabel, maka item dikatakan valid. Nilai r-hasil diperoleh dari corrected item-total correlation, sedangkan rtabel diperoleh dari: $\mathrm{df}=$ jumlah kasus -2 . Berarti $\mathrm{df}=93-2=91$ pada tingkat signifikansi 5\%, diperoleh hasil sebesar 1,136. Uji reliabilitas didasarkan atas ketentuan jika hasil alpha Cronbach lebih besar dari 0,6, maka dikatakan item adalah reliabel (handal). Untuk lebih lanjut hasil uji validitas dan reliabilitas dapat dilihat pada tabel berikut ini:

Tabel 2. Uji Validitas Variabel Kemampuan Manajerial 


\begin{tabular}{cccc}
\hline Item & r-hasil & r-tabel & Kesimpulan \\
\hline X1.1 & 0.619 & 1.136 & Valid \\
X1.2 & 0.755 & 1.136 & Valid \\
X1.3 & 0.732 & 1.136 & Valid \\
X1.4 & 0.758 & 1.136 & Valid \\
X1.5 & 0.800 & 1.136 & Valid \\
X1.6 & 0.499 & 1.136 & Valid \\
X1.7 & 0.237 & 1.136 & Valid
\end{tabular}

Sumber: data penelitian, diolah

Tabel 3. Uji Validitas Variabel Motivasi

\begin{tabular}{cccc}
\hline Item & r-hasil & r-tabel & Kesimpulan \\
\hline X2.1 & 0.274 & 1.136 & Valid \\
X2.2 & 0.387 & 1.136 & Valid \\
X2.3 & 0.654 & 1.136 & Valid \\
X2.4 & 0.731 & 1.136 & Valid \\
X2.5 & 0.766 & 1.136 & Valid \\
X2.6 & 0.618 & 1.136 & Valid \\
X2.7 & 0.580 & 1.136 & Valid \\
X2.8 & 0.321 & 1.136 & Valid
\end{tabular}

Sumber: data penelitian, diolah

Tabel 4. Uji Validitas Variabel Kepuasan Kerja

\begin{tabular}{cccc}
\hline Item & r-hasil & r-tabel & Kesimpulan \\
\hline Z1.1 & 0.177 & 1.136 & Valid \\
Z1.2 & 0.576 & 1.136 & Valid \\
Z1.3 & 0.767 & 1.136 & Valid \\
Z1.4 & 0.782 & 1.136 & Valid \\
Z1.5 & 0.803 & 1.136 & Valid \\
Z1.6 & 0.731 & 1.136 & Valid \\
Z1.7 & 0.245 & 1.136 & Valid
\end{tabular}

Sumber: data penelitian, diolah 
Tabel 5. Uji Validitas Variabel Kinerja Pewirausaha

\begin{tabular}{cccc}
\hline Item & r-hasil & r-tabel & Kesimpulan \\
\hline Y1.1 & 0.296 & 1.136 & Valid \\
Y1.2 & 0.392 & 1.136 & Valid \\
Y1.3 & 0.680 & 1.136 & Valid \\
Y1.4 & 0.692 & 1.136 & Valid \\
Y1.5 & 0.594 & 1.136 & Valid \\
Y1.6 & 0.530 & 1.136 & Valid \\
Y1.7 & 0.571 & 1.136 & Valid \\
Y1.8 & 0.649 & 1.136 & Valid
\end{tabular}

Sumber: data penelitian, diolah

Tabel 6. Uji Reliabilitas

\begin{tabular}{cccc}
\hline Variabel & Alpha Cronbach & Batasan & Keterangan \\
\hline X1 & 0.772 & 0.6 & Reliabel \\
X2 & 0.750 & 0.6 & Reliabel \\
Z & 0.762 & 0.6 & Reliabel \\
Y & 0.750 & 0.6 & Reliabel \\
\hline
\end{tabular}

Sumber: data penelitian, diolah

Berdasarkan tabel-tabel di atas terbukti bahwa seluruh item variabel penelitian ini dalam keadaaan valid (karena $\mathrm{r}$ hasil $>\mathrm{r}$ tabel) dan reliabel (karena alpha Cronbach berada di atas 0,6$)$. Sehingga layak untuk diuji ke tahap berikutnya yaitu uji hipotesis dengan menggunakan analisis regresi.

\section{Uji hipotesis pertama}

Dalam penelitian ini hipotesis 1 adalah terdapat pengaruh antara kemampuan manajerial dan motivasi terhadap kinerja pewirausaha. Hasil regresi adalah sebagai berikut:

$\mathrm{Y}=\mathrm{a}+\beta 1$ kemampuan manajerial $(\mathrm{X} 1)+\beta 2$ motivasi $(\mathrm{X} 2)+\mathrm{e}$

$\mathrm{Y}=27.127-0.009 \mathrm{X} 1+0.193 \mathrm{X} 2+\mathrm{e}$ 
Secara simultan, kemampuan manajerial dan motivasi berpengaruh terhadap kinerja pewirausaha. Hal ini ditunjukkan pada nilai $\mathrm{F}$ hitung sebesar 4.110 dengan nilai probabilitas sebesar 0.046. Karena nilai sig. F $<0.05$ maka keputusan terhadap Ho ditolak dan pengujian secara simultan dapat dilakukan atau dilanjutkan. Secara parsial, kemampuan manajerial tidak berpengaruh secara signifikan terhadap kinerja pewirausaha karena sig $=0.937>0.05$. Sedangkan motivasi berpengaruh signifikan terhadap kinerja pewirausaha karena sig $=0.046<0.05$.

\section{Pengujian hipotesis kedua.}

Dalam penelitian ini hipotesis 2 adalah terdapat pengaruh antara kemampuan manajerial dan motivasi terhadap kinerja pewirausaha melalui kepuasan kerja. Hasil regresi adalah sebagai berikut:

$\mathrm{Y}=\mathrm{a}+\beta 1$ kemampuan manajerial $(\mathrm{X} 1)+\beta 2$ motivasi $(\mathrm{X} 2)+\beta 3$ kepuasan $(\mathrm{Z})+\mathrm{e}$ $\mathrm{Y}=41.952+0.079 \mathrm{X} 1-0.352 \mathrm{X} 2-0.262 \mathrm{Z}+\mathrm{e}$

Secara parsial, kemampuan manajerial tidak berpengaruh secara signifikan terhadap kinerja pewirausaha karena sig $=0.444>0.05$. Sedangkan motivasi berpengaruh signifikan terhadap kinerja pewirausaha karena sig $=0.000<0.05$. Kepuasan kerja berpengaruh terhadap kinerja pewirausaha karena sig $=0.020<0.05$.

\section{Analisis Jalur (Path Analysis).}

Dari seluruh paparan hasil analisis regresi berganda dalam rangka pengujian beberapa hipotesis, selanjutnya dilakukan rekonstruksi jalur hubungan antara variabel satu dengan variabel yang lain. Dalam menggambar diagram jalur, untuk sementara gambar 3 menyajikan keseluruhan hubungan antara variabel satu dengan yang lain berikut koefisien beta standardized yang menyertainya.

Dengan mengambil koefisien beta standardized, maka persamaannya adalah sebagai berikut :

Kepuasan kerja $(Z)=0.080 \times 1$

Kepuasan kerja $(Z)=-0.411 X 2$

$\operatorname{Kinerja~}(\mathrm{Y})=-0.008 \mathrm{X1}$

Kinerja $(Y)=0.208 X 2$

$\operatorname{Kinerja~}(Y)=-0.240 Z$ 
Melihat model hasil uji analisis path di atas, tampak ada koefisien jalur yang tidak signifikan, yaitu jalur kemampuan manajerial (P1 dan P3). Oleh karena itu jalur tersebut dihapus, sehingga tidak tampak dalam model. Bentuk model baru disebut dengan model hasil uji perubahan analisis path seperti pada gambar berikut:

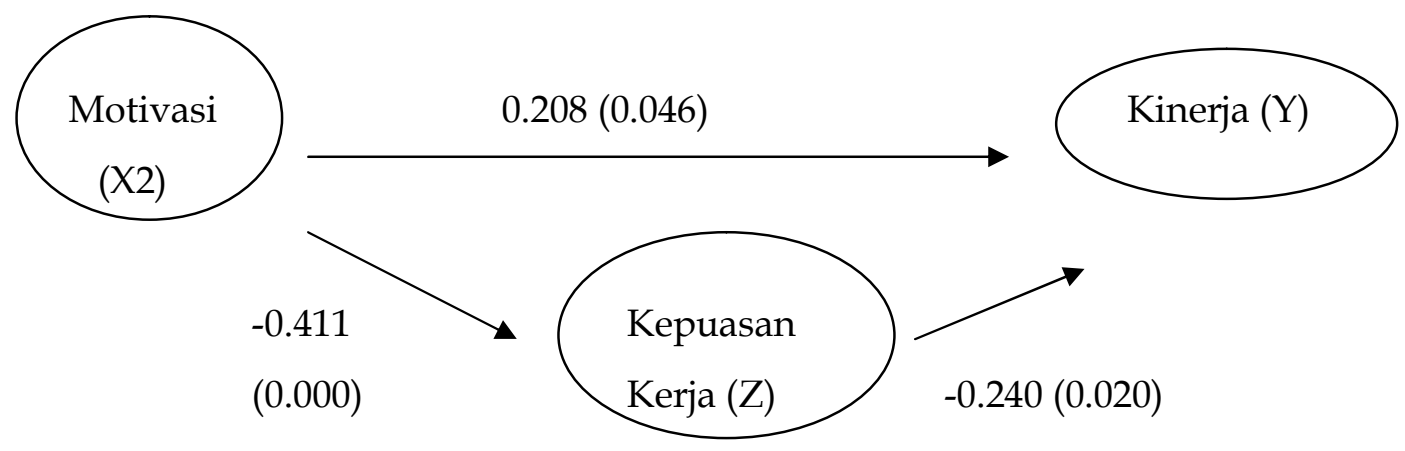

\section{Gambar 4. Hasil Uji Perubahan Analisis Path}

Berdasarkan gambar di atas dapat disusun persamaan path yang baru:

Kepuasan kerja $(Z)=-0.411 X 2$

Kinerja $(\mathrm{Y})=0.095 \mathrm{X} 2$

Kinerja $(\mathrm{Y})=0.111 \mathrm{X} 2$

\section{Perhitungan Analisis Path.}

Pengaruh langsung $\mathrm{X} 2$ terhadap $Z=-0.411$

Pengaruh langsung $X 2$ terhadap $Y=0.208$

Pengaruh langsung Z terhadap Y $=-0.240$

Pengaruh tidak langsung X2 terhadap Y melalui $Z=-0.411 \times-0.240=0.098$

Berdasarkan hasil perhitungan di atas diketahui bahwa variabel motivasi memiliki pengaruh langsung yang dominan terhadap kinerja pewirausaha dengan nilai beta terbesar yaitu 0.208 .

\section{Interpretasi Hasil Analisis.}

Hipotesis pertama adalah kemampuan manajerial dan motivasi berpengaruh terhadap kinerja pewirausaha kecil/mikro. Berdasarkan hasil analisis regresi diperoleh 
beta unstandardized untuk mengetahui pengaruh variabel kemampuan manajerial terhadap kinerja sebesar -0.009 dan sig $=0.937$. Jadi kemampuan manajerial tidak berpengaruh secara signifikan terhadap kinerja pewirausaha. Secara teoritis, kinerja adalah hasil kerja seseorang dalam melakukan aktivitas tertentu (Robbins, 2003). Dengan kemampuan manajerial yang memadai, diharapkan kinerja usaha dapat meningkat. Sama halnya dengan interpretasi hipotesis pertama yang telah dijelaskan di atas, hasil penelitian empiris (terdahulu) menggunakan obyek penelitian karyawan perusahaan. Jadi dengan kemampuan manajerial seorang pemimpin, bagaimanakah pengaruhnya terhadap kinerja karyawan perusahaan tersebut. Sedangkan dalam penelitian ini menggunakan obyek pemilik usaha.

Berdasarkan hasil analisis regresi diperoleh beta unstandardized untuk mengetahui pengaruh variabel motivasi terhadap kinerja sebesar 0.193 dan sig $=0.046$. Jadi semakin tinggi motivasi maka semakin tinggi pula kinerja. Motivasi merupakan dorongan dari dalam diri seseorang untuk melakukan suatu pekerjaan (Sule, 2008). Beberapa motivasi pewirausaha untuk menjalankan usaha mandiri ini antara lain: adanya keinginan memenuhi kebutuhan dasar, keinginan memperoleh kebebasan waktu dan finansial, ingin mengembangkan bakat, minat dan potensi, dan lain-lain. Dengan motivasi yang cukup kuat ini akan memicu diri pewirausaha kecil/mikro di wilayah Jalan Kedawung-Kalpataru Malang untuk meraih kinerja yang diharapkan. Baik dalam hal pemenuhan kuantitas kerja, kualitas kerja, peningkatan disiplin kerja, dan lain-lain. Hasil penelian ini didukung oleh penelitian Devi (2009), Narmodo dan Farid (2010), Sarworini (2007), Karweti (2010), Adonia (2007), dan Sumanto (2004).

Hipotesis dua menyatakan bahwa terdapat pengaruh kemampuan manajerial, motivasi dan kepuasan kerja terhadap kinerja pewirausaha. Secara simultan diperoleh nilai signifikansi sebesar 0.020. Hal ini menunjukkan secara bersama-sama kemampuan manajerial, motivasi dan kepuasan kerja berpengaruh terhadap kinerja pewirausaha kecil/mikro. Dengan kemampuan manajerial yang terdiri dari kemampuan konseptual, kemampuan analisis dan kemampuan sosial, maka kinerja pewirausaha dapat meningkat. Begitu juga mengenai motivasi. Jika mereka memiliki motivasi kuat untuk maju dan berkembang, maka dipastikan kinerja mereka juga akan meningkat. Kepuasan kerja yang dirasakan oleh pewirausaha dalam menjalankan bisnisnya tentu saja akan menambah produktifitas mereka dalam berusaha. 
Secara parsial, diperoleh hasil pengaruh variabel kemampuan manajerial terhadap kepuasan kerja sebesar 0.080 dan $\operatorname{sig}=0.444$. Jadi kemampuan manajerial tidak berpengaruh secara signifikan terhadap kepuasan kerja. Secara teoritis, kemampuan manajerial merupakan kemampuan pewirausaha secara umum dalam mengelola usahanya yang tercermin dalam kemampuan teknis, kemampuan manusiawi, dan kemampuan konseptual (Karweti, 2010). Dengan kemampuan manajerial yang dimiliki, maka kepuasan kerja pewirausaha akan dapat terwujud. Kepuasan kerja merupakan perasaan atau emosi positif seseorang terhadap lingkungan pekerjaannya (Robbins, 2003). Tetapi pada kenyataannya hal ini sangat berbeda aplikasinya dalam aktivitas pewirausaha kecil/mikro di wilayah Jalan Kedawung-Kalpataru Kecamatan Blimbing Malang. Bagi mereka, kemampuan manajerial dalam mengelola usahanya cukup dilakukan secara sederhana dan tidak membutuhkan keahlian yang terlalu khusus, mengingat skala usaha yang dijalankan masih skala usaha yang kecil/mikro. Berarti ruang lingkup manajemen, daerah pemasaran, dan pangsa pasar juga masih kecil.

Pengaruh motivasi terhadap kepuasan kerja sebesar -0.411 dan sig $=0.000$. Jadi motivasi berpengaruh secara signifikan terhadap kepuasan kerja (pengaruh negatif). Bagi pewirausaha kecil/mikro di wilayah Jalan Kedawung-Kalpataru Kecamatan Blimbing Malang, kepuasan kerja berkaitan dengan adanya pekerjaan yang menantang, kebebasan finansial dan waktu kerja yang dinikmati, penghargaan yang didapatkan, dan lain-lain. Bagi mereka kepuasan kerja kurang dipengaruhi oleh motivasi. Secara teoritis, motivasi merupakan keinginan seseorang untuk melakukan suatu pekerjaan (Hasibuan, 2009). Hal inilah yang mendasari seorang pewirausaha mendirikan usaha mandiri skala kecil/mikro, sesuai dengan bakat, keahlian, dan modal yang dimiliki. maka kinerja karyawan akan meningkat. Tetapi pada hakekatnya, hasil penelitian ini membuktikan bahwa terdapat pengaruh secara signifikan antara motivasi terhadap kepuasan kerja pewirausaha kecil/mikro. Hasil penelitian ini didukung oleh penelitian Prabu (2005).

Pengaruh variabel kepuasan kerja terhadap kinerja memiliki nilai beta sebesar 0.240 dan sig $=0.020$. Jadi kepuasan kerja berpengaruh signifikan terhadap kinerja (berpengaruh negatif). Sesuai dengan pendapat Robbins (2003), semakin menantang suatu pekerjaan, adanya kesesuaian antara kepribadian dengan pekerjaan, adanya dukungan rekan sejawat (karyawan), adanya kelengkapan dan ketersediaan peralatan 
dan fasilitas, akan dapat meningkatkan kepuasan kerja. Pada observasi yang dilakukan di lapangan, skala usaha dan produksi yang dihasilkan sangat dipengaruhi oleh besar kecilnya modal. Jika modalnya pas-pasan, apalagi ditunjang dengan skill yang seadanya, maka skala perusahaan juga akan tetap jalan di tempat atau kurang mengalami kemajuan yang signifikan. Demikian pula sebaliknya. Hal ini yang mendorong rendahnya tingkat kepuasan kerja. Tetapi meskipun mereka hanya memiliki fasilitas, sarana, dan prasarana yang apa adanya, tidak menyurutkan semangat pewirausaha untuk terus berjuang dan bergelut di dunia wirausaha ini. Mereka tetap berusaha memberikan layanan yang terbaik kepada konsumen. Apalagi mengingat tingkat persaingan di wilayah Kedawung - Kalpataru ini cukup tinggi. Diharapkan dalam waktu panjang, kepuasan kerja yang dinikmati oleh pewirausaha kecil/mikro di wilayah Jalan Kedawung-Kalpataru Malang ini dapat semakin meningkatkan kinerja usahanya. Pada hakekatnya, hasil penelitian ini membuktikan bahwa terdapat pengaruh antara kepuasan kerja terhadap kinerja. Hasil penelitian ini didukung oleh penelitian Devi (2009), Syaiin (2008), serta Parwanto dan Wahyuddin (2002).

Setelah dilakukan analisis yang lebih mendalam mengenai pengaruh langsung dan tidak langsung kemampuan manajerial dan motivasi terhadap kinerja melalui kepuasan kerja dengan menggunakan analisis jalur, maka diperoleh hasil bahwa pengaruh yang dominan mempengaruhi kinerja pewirausaha kecil/mikro adalah pengaruh langsung variabel motivasi (X2) dengan nilai beta terbesar yaitu 0.208.

\section{KESIMPULAN DAN SARAN}

\section{Kesimpulan}

Tujuan penelitian ini adalah untuk menguji pengaruh langsung dan tidak langsung antara kemampuan manajerial dan motivasi terhadap pewirausaha kecil/mikro melalui kepuasan kerja. Populasi penelitian adalah 186 pewirausaha kecil/mikro di wilayah Jalan Kedawung-Kalpataru Kecamatan Blimbing Malang, dengan sampel sejumlah 93 orang dengan teknik pengambilan simple random sampling. Metode analisis menggunakan analisis regresi yang dilanjutkan dengan analisis jalur (path-analysis).

Hasil uji validitas dan reliabilitas membuktikan bahwa semua item-item variabel adalah valid ( $\mathrm{r}$ hitung $>\mathrm{r}$ tabel) dan reliabel (alpha di atas 0,6$)$. Hasil regresi 
untuk menguji hipotesis pertama membuktikan bahwa secara simultan terdapat pengaruh langsung antara kemampuan manajerial dan motivasi terhadap kinerja pewirausaha kecil/mikro. Berarti hipotesis 1 diterima. Namun secara parsial, hasil regresi menunjukkan bahwa kemampuan manajerial tidak berpengaruh secara signifikan terhadap kinerja pewirausaha dengan nilai sig $=0.937>0,05$. Sedangkan motivasi berpengaruh secara signifikan terhadap kinerja pewirausaha dengan nilai sig $=0.046<0,05$. Hasil uji hipotesis kedua membuktikan bahwa tidak terdapat pengaruh tidak langsung antara kemampuan manajerial dan motivasi terhadap kinerja pewirausaha melalui kepuasan kerja. Hal ini dibuktikan dengan tidak signifikannya pengaruh kemampuan manajerial terhadap kinerja pewirausaha $(\operatorname{sig}=0.937>0.05)$, dan tidak signifikannya pengaruh kemampuan manajerial terhadap kepuasan kerja $(\operatorname{sig}=0.444>0.05)$.

Dengan menggunakan analisis jalur, ditemukan model path baru dengan menghilangkan pengaruh variabel kemampuan manajerial (X1). Diketahui nilai beta standardized pengaruh langsung motivasi $(\mathrm{X} 2)$ terhadap kinerja pewirausaha sebesar 0.208, sedangkan pengaruh tidak langsung motivasi terhadap kinerja pewirausaha melalui kepuasan kerja sebesar 0.098. Berarti variabel dominan yang berpengaruh adalah pengaruh langsung motivasi terhadap kinerja pewirausaha kecil/mikro.

\section{Saran}

Pewirausaha hendaknya terus mengasah kemampuan manajerial baik di bidang keahlian konseptual, keahlian manusiawi, dan keahlian teknik. Walaupun usaha yang saat ini digeluti masih dalam skala kecil/mikro, bukan berarti tidak memerlukan pengelolaan secara profesional. Karena setiap usaha pasti menginginkan adanya perubahan yang positif, dalam arti menginginkan kemajuan, peningkatan dan perluasan di segala bidang. Mengasah kemampuan manajerial dapat dilakukan dengan banyak cara, mulai dari yang kompleks (mengikuti berbagai pelatihan, seminar, workshop, mengikuti pameran, dan lain-lain), maupun yang sederhana (banyak membaca buku baru yang berkaitan dengan pengelolaan usaha, searching/browsing di internet, atau bergabung dengan asosiasi tertentu).

Motivasi pewirausaha dalam mendirikan usaha mandiri sudah cukup. Tetapi alangkah lebih baik lagi apabila ditambahkan motivasi untuk dapat mengembangkan usaha di masa depan. Dengan demikian akan semakin mendorong pewirausaha untuk 
dapat meningkatkan kinerjanya. Salah satu indikator tercapainya kinerja yang meningkat adalah: semakin sedikitnya keluhan pelanggan, semakin banyaknya jumlah pelanggan, semakin membaiknya layanan/service yang diberikan pada pelanggan, semakin banyaknya jumlah order/pesanan, dan lain-lain.

Kepuasan kerja dapat lebih ditingkatkan dengan menambah fasilitas, sarana, dan prasarana lain guna menunjang kelancaran dalam bekerja. Jika pewirausaha terkendala dengan modal usaha yang dimiliki, saat ini sudah banyak lembaga keuangan yang memberikan berbagai macam fasilitas kredit lunak untuk membiayai usaha kecil/mikro. Apabila kepuasan kerja bertambah, maka diharapkan kinerja pewirausaha dapat meningkat sehingga layanan yang diberikan pada konsumen dapat lebih prima lagi.

\section{DAFTAR PUSTAKA}

Adonia, Beatrix. 2007. Motivasi dan Komitmen Karyawan terhadap Prestasi Kerja Karyawan. Jurnal Eksekutif, volume 4, nomor 2, Agustus 2010.

Devi, Eva Kris Diana. 2009. Analisis Pengaruh Kepuasan Kerja dan Motivasi terhadap Kinerja Karyawan dengan Komitmen Organisasional sebagai Variabel Intervening. Tesis dipublikasikan. Pasca Sarjana Universitas Diponegoro Semarang. Http://eprints.undip.ac.id. Diakses tanggal 5 November 2011.

Hasibuan, Malayu. 2009. Manajemen Sumber Daya Manusia. Edisi Revisi. Cetakan keduabelas. PT Bumi Aksara. Jakarta.

http://duniabaca.com. Pengaruh Motivasi dan Kepuasan Kerja Terhadap Kinerja.

http://jarno.web.id. Diakses tanggal 5 November 2011

Kabai, Zainuddin. 2008. Pengaruh Kemampuan Manajerial Kepala Sekolah terhadap Kepuasan Kerja Guru di SMA Negeri Kabupaten Bantaeng. Penelitian dipublikasikan. http:/ / zaenuddin.blogspot.com. Diakses tanggal 6 Desember 2011

Karweti, Engkay. 2010. Pengaruh Kemampuan Manajerial Kepala Sekolah dan Faktor yang Mempengaruhi Motivasi Kerja terhadap Kinerja Guru SLB di Kabupaten Subang. Jurnal Penelitian Pendidikan, volume 11, nomor 2, Oktober 2010.

Narmodo, Hernowo dan M Farid Wajdi. 2010. Pengaruh Motivasi dan Disiplin terhadap Kinerja Pegawai Badan Kepegawaian Daerah Kabupaten Wonogiri. Penelitian dipublikasikan. Universitas Muhammadiyah Surakarta. Http:/ / eprints.ums.ac.id. Diakses tanggal 5 November 2011.

Parwanto dan Wahyudin. 2002. Pengaruh Faktor-faktor Kepuasan Kerja terhadap Kinerja Karyawan Pusat Pendidikan Komputer Akuntansi IMKA di Surakarta. Tesis dipublikasikan. Pasca Sarjana Universitas Muhammadiyah Surakarta. Http://eprints.ums.ac.id. Diakses tanggal 9 November 2011. 
Prabu, Anwar. 2005. Pengaruh Motivasi terhadap Kepuasan Kerja Pegawai Badan Koordinasi Keluarga Berencana Nasional Kabupaten Muara Enim. Jurnal Manajemen dan Bisnis Sriwijaya, Volume 3, nomor 6, Desember 2005.

Robbins, Stephen. 2003. Perilaku Organisasi. Edisi Bahas Indonesia. Jilid 1 dan 2. Pearson Education Asia.

Samsudin, Sadili. 2009. Manajemen Sumber Daya Manusia. Cetakan kedua. CV Pustaka Setia. Bandung.

Sari, Kartika. 2010. Pengaruh Kemampuan Manajerial Pengurus, Partisipasi Anggota dan Lingkungan Usaha terhadap Keberhasilan Koperasi di KUD Bahagia Kecamatan Gembong Kabupaten Pati. Penelitian dipublikasikan. Universitas Negeri Semarang. Http://lib.unnes.ac.id. Diakses tanggal 6 Desember 2011.

Sarworini, Fithriani. 2007. Hubungan Kemampuan dan Motivasi Terhadap Kinerja Pegawai Dinas Kependudukan, Tenaga Kerja dan Transmigrasi Kabupaten Karanganyar. Penelitian dipublikasikan. Universitas Diponegoro Semarang. Http://eprints.undip.ac.id. Diakses tanggal 7 Desember 2011.

Siswanto, HB. 2008. Pengantar Manajemen. Cetakan keempat. PT Bumi Aksara. Jakarta.

Solimun. 2002. Multivariate Analysis - SEM, Lisrel dan Amos. Cetakan 1. Universitas Negeri Malang.

Sule, Ernie Tisnawati dan Kurniawan Saefullah. 2008. Pengantar Manajemen. Edisi Pertama. Cetakan Ketiga. Kencana Prenada Media Group. Jakarta.

Sujendro, Oktavi Imam. 2007. Pengaruh Kemampuan Manajerial Kepala Sekolah, Motivasi Kerja Guru dan Tingkat Pemenuhan Kebutuhan Guru terhadap Kepuasan Kerja Guru di SMA Negeri Kabupaten Purbalingga. Penelitian dipublikasikan. Universitas Negeri Semarang. Http:// library.uny.ac.id. Diakses tanggal 5 Desember 2011.

Sumanto. 2004. Pengaruh Kemampuan Manajerial, Gaya Kepemimpinan dan Motivasi Kepala Sekolah terhadap Kinerja Guru di MTsN Plupuh Kabupaten Sragen. Tesis dipublikasikan. Universitas Muhammadiyah Surakarta. Http://eprints.ums.ac.id. Diakses tanggal 7 November 2011.

Syaiin, Subakti. 2008. Pengaruh Kepuasan Kerja terhadap Kinerja Pegawai Klinik Spesialis Bestari Medan. Tesis dipublikasikan. Pasca Sarjana Universitas Sumatera Utara. Http://repository.usu.ac.id. Diakses tanggal 8 November 2011.

www.wikipedia.org. 